\title{
An Institutional rerspective on the Ditrusion of International Management System Standards: The Case of the Environmental Management Standard ISO 14001
}

\author{
Magali A. Delmas and Maria J. Montes-Sancho
}

\begin{abstract}
This paper analyzes how national institutional factors affect the adoption of the international environmental management standard ISO 14001, using a panel of 139 countries from 1996 to 2006 . The analysis emphasizes that during the emerging phase of the standard, the potential lack of consensus within the constituents of the national institutional environment concerning the value of a new standard could send mixed signals to firms about the standard. The results show that in the early phase of adoption, regulative and normative forces within the institutional environment can work against each other. Results also show that regulative or coercive forces play a relatively more important role in the early phase of adoption of the standard than in the subsequent phases of diffusion. In the later phases of diffusion of ISO 14001, normative forces, such as the diffusion of other management standards, as well as factors related to trade, play a more important role. Because of the similarities between environmental management standards and corporate social responsibility standards, this study can help identify some of the challenges for diffusion of ISO management standards in the area of social responsibility.
\end{abstract}

\section{INTRODUCTION}

$\mathrm{T}$ HE LAST DECADE has seen the emergence of many voluntary international standards aimed at guiding corporate social and environmental responsibility. These include the UN Global Compact, the International Environmental Management System Standard ISO 14001, and the Global Reporting Initiative. Because these standards are very recent, we still have little understanding of how they diffuse internationally and over time, and more specifically whether and how they all fit within national institutional environments or cultures. In this paper, we provide an institutional perspective to help us better understand the factors that facilitate or hamper the global diffusion of environmental and corporate social accountability standards. Our goal in this article is to answer the following research questions: "What are the institutional factors that facilitate the diffusion of an international management standard in the area of the environment?" and "Do these factors differ in the early phase of adoption of the standard from its later phases of diffusion?"

To conduct our analysis, we build on research in organizational theory, in which the diffusion of management standards is a central topic. This line of research has made important strides in providing an understanding of the factors that facilitate 
the diffusion of international management standards. In particular, previous research shows national governments and corporations as being important actors, facilitating or hampering the adoption of organizational practices (Delmas \& Terlaak, 2002; DiMaggio \& Powell, 1983; Guler, Guillen, \& MacPherson, 2002; Kelley \& Arora, 1996; Russo, 2001; Tolbert \& Zucker, 1983). Most of this literature, however, treats government pressure as coercive and monolithic, whereas in reality the legal environment is likely to be more complex. Indeed, the legal institutional environment includes not just the coercive pressure that can be exercised through formal regulations but also informal practices, norms, and interpretation of the law (Edelman, Uggen, \& Erlanger, 1999; Sutton \& Dobbin, 1996). Studying the role of national governments is particularly important for environmental and ethics standards, which are often used to complement efforts by legislation to better address social and environmental issues (Gilbert \& Rasche, 2007). Analyzing the interaction among different constituents of the institutional environment is particularly important in the initial phase of adoption of such standards, when the standards are not yet institutionalized, as some of the constituents may contest them.

Furthermore, most attention has focused either on the diffusion of established practices or on the early adoption of practices but has rarely taken a longitudinal approach covering a decade of data. The most recent international comparative research on the diffusion of the international environmental management system standard ISO 14001 emphasized the role of the national institutional environment and the role of forces related to trade as drivers of the early adoption of ISO 14001 (Albuquerque, Bronnenberg, \& Corbett, 2007; Corbett \& Kirsch, 2001; Delmas \& Montiel, 2008; Neumayer \& Perkins, 2004; Prakash \& Potoski, 2006, 2007; Potoski $\&$ Prakash, 2004). However, these studies focused mostly on the early years of the diffusion of ISO 14001 or concentrated on a specific industry setting. ${ }^{1}$ In comparison, our study uses eleven years of data, allowing a comparison between early and later phases of the diffusion of the standard.

In this paper, we contribute to the emerging literature on international environmental and corporate social accountability standards and develop the analysis of the diffusion of management standards in new directions. We contribute to both existing work on the diffusion of international management standards and to neoinstitutionalist research. We extend the literature on the diffusion of international management standards by showing how the elements of a national institutional context can favor or hamper the diffusion of an emerging international standard and how the importance of these elements varies over time. We enrich the institutional framework by proposing that institutional forces can work against each other. We highlight the potential tension between the regulative and normative aspects of the legal environment in the early phases of the institutionalization of an international environmental management standard. We differentiate between the elements that help the initial take-off of a standard and those of its later diffusion. Our findings can be helpful in informing future diffusion patterns of international management standards in the area of social responsibility.

We illustrate these points by examining the early and later phases of adoption of the international environmental management standard ISO 14001-a standard 
established in 1996, for which there is documented information on the number of certifications per country. Our findings show that ISO 14001 is more likely to be adopted early in a country with a high level of governmental commitment to environmental protection, a low to moderate number of law firms per capita, and an active civil society. We find that these factors fade in later phases of diffusion. The role of trade relations and the presence of ISO 9000 prove to be important factors both in early and later phases of diffusion. The standard also diffuses through geographical proximity but only in the later phases of diffusion.

We begin with a survey of the institutional literature on the diffusion of management practices, and then review the case of the ISO 14001 standard. Based on these reviews, we next develop and test hypotheses on the role of the institutional environment in the early and later phases of diffusion of international management practices. We then offer a concluding discussion on the impact of our findings for the development of international standards in the area of corporate social responsibility.

\section{INSTITUTIONAL ENVIRONMENT AND ADOPTION OF MANAGEMENT STANDARDS}

Institutionalization involves "the processes by which social processes, obligations or actualities come to take on a rule-like status in social thought and action" (Meyer \& Rowan, 1977: 41). To date, however, institutional theory has paid relatively little attention to the early processes of institutionalization (Ritti \& Silver, 1986; Tolbert \& Zucker, 1983). In a rare exception, Tolbert \& Zucker (1996) have suggested three basic stages of institutionalization of a management practice: preinstitutionalization, semi-institutionalization, and full institutionalization. In this typology, the initial pre-institutionalization stage is characterized by few adopters and by limited knowledge about the practice. In the semi-institutionalization stage, the practice is fairly diffused but not yet permanent and stable and may instead have a "fashionable" or "fad" quality (Abrahamson \& Fairchild, 1999). In the third and final stage of full institutionalization, the practice is said to have "become taken for granted by members of a social group as efficacious and necessary" (Tolbert \& Zucker, 1996: 179).

In terms of this typology, most research to date in the management literature has focused on the third and final stage, or on what happens during the transition between the second and third stages. Some researchers, for example, have noted the effects of national institutions and forces on the process of diffusion of certain organizational practices within countries (Abrahamson \& Fairchild, 1999; Lazerson, 1995). Others have more specifically considered the institutional factors that shape the cross-national diffusion of practices, focusing on state structures, professionalization, and culture as explanations (Guillen, 1997; Meyer, Boli, Thomas, \& Ramirez, 1997; Westney, 1987). Some have also argued that countries should not be studied in isolation, but that how countries relate to each other in the global trading system strongly influences the diffusion of practices (Guler et al., 2002). This paper, by contrast, will focus on the pre-institutionalization and semi-institutionalization 
stages, during which there is still a lack of consensus on the value of the organizational innovation.

Tolbert \& Zucker (1996) argue that the movement toward a more permanent and widespread status rests heavily on what the authors call the "objectification" that accompanies the diffusion of a management practice. According to these authors, objectification involves the development of some degree of social consensus among organizational decision makers concerning the value of a practice, and the increasing adoption by organizations on the basis of that consensus. In the emerging phase of an international management standard, the lack of social consensus on the practice may manifest itself at the national level, or there may be differences in the interpretation of the standard across countries. Understanding what constitutes the basis of the interpretation of the value of a management standard when there is no evidence of its technical efficiency is important. We argue that the regulative and normative context in which the standard is implemented matters. The risks of the standard may be accentuated in some national contexts, whereas the potential benefits may be emphasized in others. Even within the same national context, some constituents of the institutional environment may contest the value of a management standard while others promote it. The emerging phase of a standard provides a unique opportunity to analyze the web of institutional forces that shape and guide the diffusion of a standard. Our empirical setting allows us to compare this early phase of diffusion to later phases.

Recognizing the importance of studying different phases of institutionalization, however, is not the same as doing it. The main empirical challenge is that by the time diffusion has clearly reached Tolbert and Zucker's "second stage," some of the key details of the early days may have faded from memory or otherwise become difficult to reconstruct. On the other hand, focusing only on the pre-institutionalization does not allow comparative analysis over time. The standard for the improvement of environmental management practices developed by the International Organization for Standardization (ISO), namely ISO 14001, provides a particularly promising possibility in this connection. An existing body of work has focused on the spread of another international standard from the same organization, ISO 9000, generally known as the Quality Management Standard. Because of the lack of data from the early stage of its adoption, however, research on the ISO 9000 standard focuses mainly on the later stages of diffusion, by which time a large number of companies in a large number of countries had adopted the standard (Casper \& Hancke, 1999; Guler et al., 2002; Mendel, 2001). By contrast, obtaining data even on the first years of the adoption of ISO 14001 is possible, and the adoption process for this more recent standard has now progressed far enough to provide us with an excellent opportunity to compare the institutional dynamics of the take-off period to the later phases the diffusion process. Although many other standards in the area of corporate sustainability have emerged in recent years, including the Global Reporting Initiative and the UN Global Compact, the longitudinal data available is not yet sufficient to allow us to compare early adoption of the standards to later phases of diffusion. Before turning to the details of the case study and its findings, considering the basic background for the ISO 14001 standard may be useful. 
International management standards in the area of the environment and corporate social responsibility are designed to allow stakeholders to systematically evaluate the social, environmental, and ethical performance of corporations (Gilbert \& Rasche, 2007; Gray, Kouhy, \& Lavers, 1995). These environmental and corporate social accountability standards represent voluntary initiatives to complement legislation efforts to better address social and environmental issues (Gilbert \& Rasche, 2007). International environmental and corporate social accountability standards are relatively diverse. They differ with regard to the issue and the processes they standardize, and the organization itself, its stakeholders, or third-party independent organizations guarantee adherence to these standards (Gilbert \& Rasche, 2007). Some standards focus exclusively on the social dimension (e.g., SA8000), whereas others are mainly concerned with environmental performance (ISO 14001) (Rasche \& Esser, 2006). Still others, such as the Global Reporting Initiative, focus on the economic, social, and environmental aspects of organizations' operations (Manetti \& Becatti, 2009). However, all of these standards have something important in common: they consist of rules to guide the creation of an entire class of management systems. Because of this commonality, they have been labeled as "meta-standards" (Uzumeri, 1997).

Formally adopted in 1996 by the ISO, ISO 14001 was one of the first international environmental management standards. ISO 14001 was designed to help firms identify and control the environmental impact of their activities, products, or services and to help stakeholders recognize firms committed to improving their environmental impact. As of 2006, 129,199 organizations in 140 countries had adopted ISO 14001, but the level of adoption still differed greatly across countries, with 44 percent of the worldwide ISO 14001-certified facilities located in Western Europe and 41 percent in the Far East (ISO, 2006). The top ten countries by 2006 accounted for approximately 72 percent of the world ISO 14001 certifications. Of these ten countries, six were member states of the European Union (ISO, 2006). U.S.-certified facilities accounted for only 4 percent of ISO 14001-certified facilities (ISO, 2006).

The ISO 14001 standard shares many common traits with its predecessor, ISO 9000 , the international standard for quality management. Like ISO 9000, ISO 14001 does not focus on outcomes, such as pollution, but focuses on processes. Also like its predecessor, ISO 14001 involves the possibility of an audit by a third party, meaning that studies of ISO standards can benefit from the luxury of third-party auditing and verification.

In essence, the ISO 14001 standard describes the basic elements of an effective Environmental Management System (EMS). The underlying logic is that if organizations set out to manage environmental matters systematically, they can be expected to learn about production processes that result in pollution, take action against them, and perform better than firms that do not (Coglianese \& Nash, 2001). These elements include creating an environmental policy, setting objectives and targets, implementing a program to achieve those objectives, monitoring and measuring the program's effectiveness, correcting problems, and reviewing the system to improve 
both the program and the firm's overall environmental performance (Andrews et al., 2003).

Although there are many similarities between ISO 9000 and ISO 14001, there are two main differences, both of which reflect the fact that ISO 14001 focuses on environmental performance in particular. First, given that environmental performance is highly regulated in most industrialized countries, ISO 14001 allows the examination of the role of the regulatory environment in the diffusion of a management standard. Second, given the widespread (albeit not universal) belief among business managers that improved environmental performance is likely to come at the cost of reduced economic performance, the actual impact of ISO 14001 on environmental performance is by no means guaranteed. ISO 14001 does not establish absolute requirements for environmental performance-other than a commitment to compliance with applicable regulations-and it does not explicitly identify environmental performance as a factor in the actual certification process (Christmann and Taylor, 2001).

This last point is all the more important in light of the fact that although the costs of ISO 14001 certification are very real-ranging from $\$ 50,000$ for small firms to more than $\$ 200,000$ for larger firms (Watkins and Gutzwiller, 1999)-the benefits of adopting ISO 14001 are still unclear and they remain subject to interpretation even seven years after the creation of the standard (Andrews et al., 2003). The potential benefits, moreover, are expected to accrue not only from potential improved environmental performance, but also from avoiding damaging impacts-a process that is difficult to evaluate (Bansal and Bogner, 2002). For example, companies may experience a decrease in the cost of their regulatory fines, as well as a decrease in their environmental liabilities, quantifying the dollar value of an avoided lawsuit is more difficult for a firm than quantifying a payment that actually needs to be made. As another example, although ISO 14001 procedures may ultimately lead to operational efficiencies through involving employees in the design and implementation of the standard, no study has yet documented the efficiency gains resulting from the adoption of ISO 14001 (Delmas, 2001).

This very uncertainty, however, also contributes to the value of ISO 14001 as a case study, particularly as examined through an institutional lens. According to institutional theory, decision makers will be especially sensitive to institutional pressures when they face uncertainty regarding the tangible benefits of an organizational practice. Still, the benefit of studying ISO 14001 is perhaps best obtained through comparative research, whereas most research on ISO 14001 to date has highlighted the importance of institutional factors within a specific country or industry (Bansal and Bogner, 2002; Christmann and Taylor, 2001; Delmas, 2002; Kollman and Prakash, 2002; Russo, 2002). To be sure, this research has had value, noting in particular that the adoption of ISO 14001 can signal to external stakeholders that the company is willing to improve its environmental performance--although the signal may be more or less effective, depending on the context. The value of the signal is limited-for example, when stakeholders see the standard as a procedural smokescreen, rather than believing firms are actually improving their environmental performance (Delmas, 2000). 
By 2001, ISO 14001 could be seen as moving toward the conditions defining the semi-institutionalized period of diffusion of a practice proposed by Tolbert and Zucker (1996). On the one hand, no clear agreement existed on the value of ISO 14001 , but on the other hand, the standard had become fairly widely diffused, with nearly 40,000 certifications in place worldwide (ISO, 2005). By 2001, more than 50 percent of the countries in the world had adopted ISO 14001 (See Figure 1). In addition, the ISO revised the standard in 2000 in light of the experience from its early diffusion. The period of 1996-2000 can therefore be considered the take-off period, whereas the period of 2001-2006 can be considered the semi-institutionalization period. Because we now have eleven years of adoption data, we are able to compare the take-off period of adoption of ISO 14001 to the following phase of adoption. Of course, studying ISO 14001 has some limitations: no comparable longitudinal information is available on the adoption of ISO 14001 per sector.

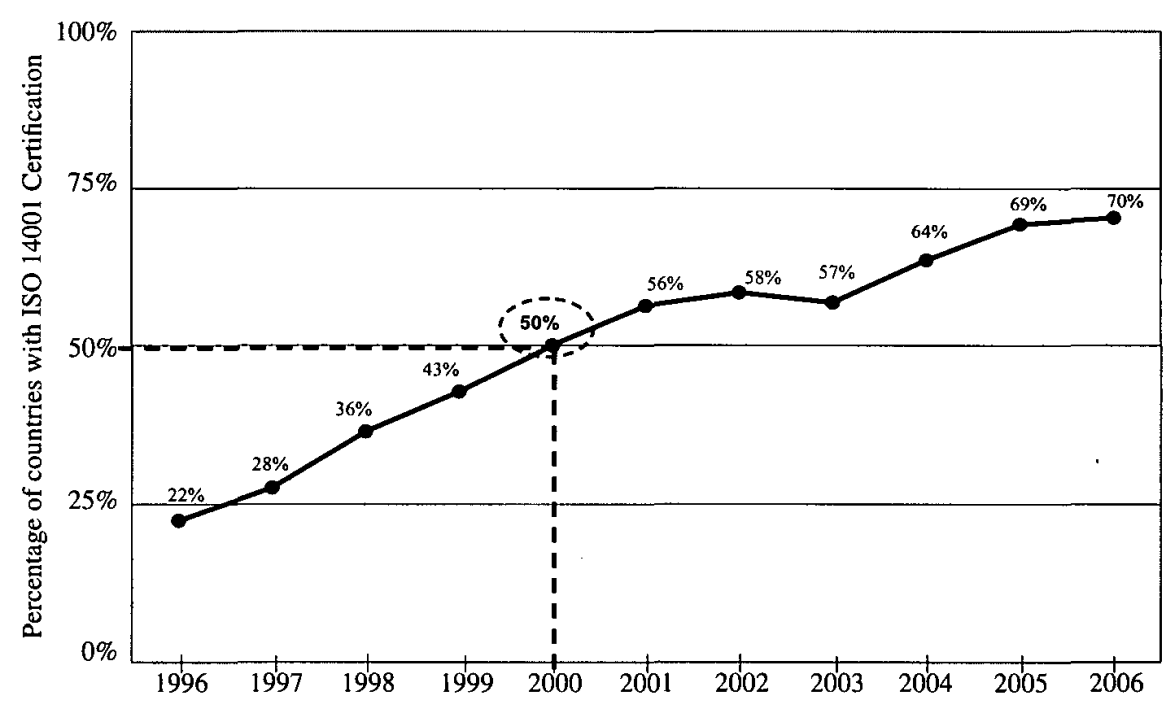

Figure 1: Penetration of ISO 14001 certification in UN member countries (192) from 1996 to 2006

\section{Hypotheses: In Search of ISO}

The institutional sociology approach proposes that regulative, normative, and cognitive aspects of the institutional environment impact the adoption of organization practices (Scott, 1995). The regulative view stresses conformity to rules and the exercise of rewards and penalties. It includes coercive isomorphism, which refers to the homogeneity pressures stemming from political influence and the need to achieve legitimacy within a context. The normative pillar of the institutional environment refers to sets of expectations, within particular organizational contexts, of what constitutes appropriate and legitimate behavior (Scott, 1995). In other words, Scott's normative pillar is grounded in what is appropriate, that is, what is expected of organizations. Much of the writing on normative constraints emphasizes how normative expectations assume a taken-for-granted form; the ways of organizing become unquestioned, and alternatives become unthinkable (Zucker, 1983). The 
cognitive aspects of the institutional environment refer to the cultural elements that govern choice often without receiving conscious thought (DiMaggio \& Powell, 1983; Hoffman and Ventresca, 1999; Zucker, 1983).

The institutional literature argues, in the case of the adoption of technological and management practices, that first movers and followers face different levels of institutional pressure (DiMaggio \& Powell, 1983; Tolbert \& Zucker, 1983). Using the case of the diffusion of civil service reform, Tolbert and Zucker demonstrate that first movers are mainly interested in the technical efficiency of a practice, whereas followers are more subject to institutional pressure. They argue that first movers adopt management practices because of "real needs." On the contrary, followers do not implement a practice because of its merits but because other organizations do. Similarly, Westphal, Gulati, and Shortell (1997) show that early adopters of total quality management practices in hospitals seek efficiency gains, whereas later adopters aim at increasing their legitimacy.

Building on institutional theory, we argue below that countries where the international standard ISO 14001 was first adopted are marked by different institutional pressures than those where ISO 14001 was adopted later. We argue that regulative or coercive pressures tend to have a greater impact on the adoption of ISO 14001 in the take-up phase of the diffusion of the standard but may fade over time, whereas normative and cognitive forces tend to be more effective at promoting the standard in the later phases of diffusion. In other words, regulative pressures associate rewards and/or penalties with the adoption of ISO 14001 and provide some evidence to potential adopters about the benefits of adoption. In the second phase of diffusion of the standard, once ISO 14001 has been adopted in more than half of the countries in the world and has gained more legitimacy, normative pressures become more effective at predicting adoption. However, we argue that normative forces resisting the standard can also be present in the early phase of the standard, which is marked by a lack of social consensus among organizational decision makers concerning the value of a practice. More specifically, we contend that normative forces can oppose coercive forces within national regulatory environments. Such resisting forces fade over time, once the standard has been adopted in the majority of the countries.

We first develop hypotheses on the role of government, corporations, and environmental NGOs as exerting coercive pressure for the early adoption of ISO 14001 . We subsequently present a hypothesis on the negative role normative elements can play in the early phase of development of a standard, based on the case of interpretation of the law by compliance professionals. Finally, we generate hypotheses on the positive role of normative and cognitive institutional forces on the later diffusion of ISO 14001 . These include the role of previous experience with international quality management standards, and of geographical proximity.

Government Commitment toward the Environment

Research has documented that nation-states, especially if they have an active strategy to accelerate economic growth, are key to the diffusion of new practices borrowed from other countries (Arias and Guillen, 1998). As such, the cross-national diffusion of innovation is highly dependent on the coercive role of the state in each country. 
States may provide incentives (or implement sanctions) for organizational transformation. In addition, as consumers of goods and services, states may exert coercive pressure by asking suppliers and contractors to conform to certain procedures and standards. Many organizational studies have reported the state's role in imposing the adoption of a practice (Kelley and Arora, 1996; Tolbert \& Zucker, 1983).

Scholars in the institutional economics tradition have analyzed how the interplay between government action and the structure of a nation's political institutions can shape the ability of a company to make private investments (Levy and Spiller, 1994). Given that firms are especially dependent on the legal environment regarding environmental protection, governmental commitment to environmental protection is particularly important in explaining the diffusion of environmental management standards. Researchers have shown that the political context is key to explaining the adoption of ISO 14001 (Delmas, 2002; Neumayer \& Perkins, 2004; Potoski \& Prakash, 2004). Because ISO 14001 is a management system that goes beyond existing command-and-control regulations, firms may see ISO 14001 as a tool to help their organizations respond to stringent regulations. A government's commitment to the environment will therefore increase the perceived benefits of adopting ISO 14001. In the presence of uncertainty over government commitment to environmental protection, by contrast, fewer incentives will exist for firms to invest in ISO 14001 efforts. Contexts of uncertainty regarding governmental commitment may lead to more questioning of the actual value added by an unclear emerging standard than by a more mature standard that provides clearly identified benefits. Delmas and Montiel (2008) also showed how government commitment to the environment facilitated the early adoption of ISO 14001 in the chemical industry.

In addition, the attitude of governments toward environmental management standards should play a role in helping their diffusion. As such, governments that are sympathetic to such standards will be able to provide incentives to firms seeking their adoption or threats to firms that are not adopting the standard. Governments that devote resources to the design of the standard through participation in the workgroups of the ISO or by issuing a government environmental standard are more likely to be motivated to facilitate the initial adoption of the standard in their country. Likewise, governments that devote resources to the implementation of a government-funded environmental management system standard would be more likely to support ISO 14001. For example, the Eco-Management Audit Scheme (EMAS), the first international EMS standard, was developed by the European Commission and benefited from strong support by European authorities and European member states that promoted its diffusion into European firms. The European authorities and European countries facilitated the development of a certification system with "verifiers" and consulting companies. These factors reduced the search and information costs for European firms (Delmas, 2002). Furthermore, governments can also promote the adoption of ISO 14001 by threatening to issue a mandatory environmental management standard (that may be more stringent than ISO 14001) if firms are not voluntarily adopting ISO 14001 in its present form. For example, although the European EMAS was voluntary, the European Commission did retain the right to adopt compulsory registration in the future, adding power to the legisla- 
tive impetus towards environmental audit (Delmas, 2002). When the EMAS was reviewed in 1999, there was therefore a potential threat for firms that the European Commission would decide to transform EMAS into a mandatory environmental management scheme, hence a legitimate institution (Delmas, 2002).

We argue that these two elements, experience and regulatory promotion of the standard, facilitated the development of ISO 14001 in Europe by limiting transaction costs associated with the adoption of the standard and favoring the demand for ISO 14001 from stakeholders in the early phases of diffusion of the standard. Such factors would become less prevalent once the standard had diffused within and among countries. The role of government commitment on the adoption of ISO 14001 should therefore be more important in the first years of adoption of the standard, the pre-institutionalized period, than in the later years of diffusion of the standard. We therefore hypothesize the following:

Hypothesis 1a. The greater the government commitment to environmental protection, the greater the propensity for ISO 14001 certification within that country in the early phases of adoption of the standard.

Hypothesis $1 \mathrm{~b}$. The greater the participation of a government in the design of ISO 14001 , the greater the propensity for ISO 14001 certification within that country in the early phases of diffusion of the standard.

Hypothesis 1c. The greater the number of existing EMAS certifications within a country, the greater the propensity for ISO 14001 certification within that country in the early phases of diffusion of the standard.

The Role of NGO Pressure

In addition to governments, the community in the form of non-governmental organizations (NGOs) may exert pressure on businesses to adopt certain practices and may assist in the diffusion of ideas among their member countries. Meyer, Frank, Hironaka, Schofer, and Tuma (1997) showed that the global spread of environmental discourse and organizations is especially stimulated by non-governmental actors such as the UN. NGOs have become sophisticated communicators and are perceived as instigators of change in the global marketplace. Studies show that under increasing pressure from environmental and labor activists, multilateral organizations, and regulatory agencies in their home countries, multinational firms are adopting international environmental standard certification such as ISO 14001 (Gereffi, Garcia-Johnson, and Sasser, 2001).

ISO 14001 may help firms respond to NGO environmental pressures by enabling them to improve their environmental performance and communicate with NGOs. In turn, the involvement of civil society in NGOs may be seen as another support group helping the diffusion process of ISO 14001. In their cross-sectional analysis of the international adoption of ISO 14001, Potoski and Prakash (2004), Neumayer and Perkins (2004), and Delmas and Montiel (2008) found that countries whose citizens join international NGOs have more ISO 14001 certifications. Implementing an ISO 14001 EMS encourages companies to write their environmental statements, have people designated to respond to NGO demands, and organize information within 
the firm so it is easily accessible, documented, and organized. Moreover, by having a system in place, disclosing information to NGOs and the community when any problems or complaints arise may be easier. We argue that the impact of international NGOs on the adoption of ISO 14001 may be more significant in the early phases of adoption of the standard when the standard is still novel. Once the standard is more widely diffused, NGOs may be already promoting other more novel environmental management practices or standards. We thus expect the following:

Hypothesis 2. The greater the number of international NGOs within a particular country, the greater the propensity for ISO 14001 certification within that country in the early phase of adoption of the standard.

The Role of Trade Relations

In addition to the government and NGOs, firms are an influential type of organization that may cause coercive isomorphism. For example, multinationals are widely recognized as key agents in the diffusion of practices across national borders, through the transmission of organizational techniques to subsidiaries and to other organizations in the host country (Arias and Guillen, 1998; Christmann and Taylor, 2001). One specific instance of this mechanism is the 1999 request of the Big Three American automakers (Ford, General Motors, and Chrysler) that all their suppliers adopt ISO 14001 (Delmas \& Montiel, 2009).

Firms that are trading with countries where an important number of local firms have adopted a management standard may need to adopt the same standard to trade with these countries or to trade with local firms there. Firms will therefore adopt the standard to be able to trade with local firms. Guler, Guillen, and MacPherson (2002) have shown such behavior, which they call "cohesion in trade," in the case of ISO 9000. Xia, Wang, Wang, and Xing (2008), Albuquerque et al. (2007), and Prakash and Potoski (2007) confirmed this effect in their analyses of the diffusion of ISO 14001.

Although institutional forces can be associated with specific types of organizations, an organization, or some specific elements of that organization, might exert simultaneously coercive, normative, and/or cognitive pressures. For example, although institutional theory explains how pressures originating from powerful actors, such as government, corporations, or activists, are the most direct mechanism of institutional diffusion (DiMaggio \& Powell 1983), pressures originating from such actors might take a normative form. Some firms can, for example, exert coercive pressure on their suppliers, whereas other firms may imitate the behavior of competing firms. Furthermore, coercive pressure from powerful actors can also be transformed into a normative pressure when a significant number of organizations have adopted a standard.

Countries that compete with one another in efforts to trade to third countries may well imitate the behavior of the countries with which they are competing (Guler et al., 2002). Firms may adopt the same practices because not doing so would disadvantage them relative to the competition and erode their edge in the market place. According to this argument, firms competing in countries that have a higher 
adoption rate of ISO 14001 should mimic their competitors' behavior and adopt ISO 14001. Likewise, Guler, Guillen, and MacPherson found this behavior, which they called "role equivalence in trade," to be a significant driver of the adoption of ISO 9000 . Although the role of cohesion in trade, a coercive pressure, should be effective in the early phases of adoption of the standard, the importance of trade relations should still be present in later phases of diffusion of the standard as more and more organizations adopt the standard in countries with which the focal country trades. Likewise, cohesion in trade, which has a more normative function, should also increase with the diffusion of ISO 14001 . We formalize the role of trade relations as follows:

Hypothesis 3a. The greater the number of ISO 14001 certifications in countries with which the focal country is trading-representing cohesion in trade-the greater the propensity for ISO 14001 certifications in the focal country in the early and later phases of diffusion of the standard.

Hypothesis $3 \mathrm{~b}$. The greater the number of ISO 14001 certifications in countries with which the focal country is competing-representing what the literature calls "role equivalence in trade" - the greater the propensity for ISO 14001 certification in the focal country in the early and later phases of diffusion of the standard.

Resistance to ISO 14001: Interpretation of the Law by Compliance Professionals In the institutional sociology perspective, the normative pillar of the institutional environment refers to sets of expectations, within particular organizational contexts, of what constitutes appropriate and legitimate behavior. In the case of the legal environment, what constitutes "appropriate and legitimate" may be subject to interpretation. Edelman (1992), Edelman, Uggen, and Erlanger (1999), and Sutton and Dobbin (1996) have argued that law is shaped by the social realms it seeks to regulate, and that legal ambiguity in regulations can leave organizations with substantial latitude for constructing the meaning of compliance. These authors explain that compliance professionals (such as lawyers) act as social filters through whom legal ideas pass on their way to organizations, and through whom organizational constructions of law are likely to pass on their way back to the legal realm (Edelman et al., 1999). Indeed, when lawyers present the legal environment to the business world, they also provide their interpretation of the law and what they consider is appropriate for regulation compliance.

An international standard will be implemented in various national legal environments. Given that levels of litigation can vary significantly from one nation to another, it needs to be recognized that the potential for the discovery of previously unidentified or unresolved regulatory violations may discourage some firms from considering the adoption of ISO 14001. As Rodgers (1996) has noted, in other words, the potential for violations to be identified during the implementation phase or during self- or third-party audits can lead to potential liabilities-raising as well the possibility that regulatory agencies could use the ISO 14001 process to take legal actions against even ISO-certified firms (Orts and Murray, 1997). In a survey sent 
to 200 U.S. firms that were certified before 1999,62 percent of the firms identified uncertainty about the regulatory agencies' potential "utilization of EMS audit information" as a constraint to the adoption of ISO 14001, and 60 percent indicated "potential legal penalties from voluntary disclosure" as a constraint to the adoption of ISO 14001 (Delmas, 2000). In the case of ISO 14001, the ambiguity in the law regarding the benefits of the standard leaves room for environmental lawyers to provide their own interpretation of the standard's potential value. Because part of the mission of lawyers is to be conservative to protect their clients, they will likely highlight the negatives of the standard. For example, the U.S. environmental law literature is replete with articles on the risks of adopting ISO 14001 for corporations (Mostek, 1998; Orts and Murray, 1997; Rodgers, 1996). In summary, because ISO 14001 departs from a traditional compliance model in which firms do not disclose any information about their potential problems, and instead encourages firms to gather information about latent areas of non-compliance, conservative compliance professionals might oppose the standard.

Such problems would appear to be greater in countries marked by a high level of litigation and adversarial relations between stakeholders, such as the United States, where methods of policy implementation and dispute resolution are more adversarial and legalistic than in European countries (Kagan, 2001). With time, of course, the uncertainty concerning potential litigation may well diminish: if no cases of litigation are linked to the adoption of ISO 14001, lawyers will realize that firms that adopted the standard did not suffer from liabilities. The importance of compliance professionals in a litigious society should therefore be more important for an emerging standard than for an established standard. We argue that the greater the number of environmental lawyers in a society, the more likely resistance to the ISO 14001 standard in that country will be. Therefore, we formalize our second proposition as such:

Hypothesis 4. The greater the number of environmental lawyers within a country, the lower the propensity for ISO 14001 certification within that country in the early phase of adoption of the standard.

Diffusion of Other Management Standards

Past experience with existing management standards may also influence the set of expectations of an emerging management standard. This correlation is especially true if professionals related to the adoption of the earlier standards may benefit from the adoption of the new standard. As described above, ISO 9000, the international quality management standard, was a precursor of ISO 14001, having been adopted in 1987. Because of the similarities between these standards and their implementation, positive experience with ISO 9000 should have a positive impact on how companies perceive ISO 14001.

The institutional literature has described how what has been referred to as "champions"- that is, a set of individuals with a material stake in the promotion of such a standard - can influence the objectification and diffusion of management standards (DiMaggio, 1988; Kagan, 2001; Tolbert \& Zucker, 1983). In particular, 
management consultants are often active in providing advice to companies on the decision to adopt management standards (see, e.g., the literature on the adoption of total quality management standards including Reeves and Bednar [1994] and Sitkin, Sutcliffe, and Schroeder [1994]). These consultants benefit directly from the diffusion of ISO standards, which increases their potential market for services.

Because ISO 14001 and ISO 9000 bear commonalities, consultants and certifiers of ISO 9000 often become consultants and certifiers of ISO 14001 (Mazurek, 2001), often having the opportunity to provide information about ISO 14001 certification during the process of advising their clients about ISO 9000 . Evidence shows that firms that have adopted ISO 9000 are more likely to adopt ISO 14001 (Darnall, 2003). Therefore, in a country where a significant number of firms have adopted the ISO 9000 standard, consultants and firms will likely have more knowledge about how to implement ISO 14001 than a country with few ISO 9000 standards. Several previous studies confirm this assertion (Corbett \& Kirsch, 2001; Delmas \& Montiel, 2008; Moon and DeLeon, 2005; Potoski \& Prakash, 2004; Xia et al., 2008).

Again, the role of professionals is key at this emerging phase, when firms need more help in understanding how to implement the standard. However, unlike for government commitment and litigation, professionals are likely to continue to push for the adoption of the standards once the standard has diffused more broadly. If the number of consultants and certifiers increases over time, adopting the standard will become even easier. Furthermore, these professionals will have a direct stake in the further diffusion of the standard. We therefore predict that the diffusion of previous management standards will facilitate the early adoption of ISO 14001 via the normative pressure management consultants involved in ISO 9000 exert and that this effect will increase over time. We therefore expect that the more ISO 9000 certificates there are, the more management professionals will be involved in providing consulting services for the quality standard, and the more likely it is that these professionals will push for the standard ISO 14001. We formalize the role of the diffusion of other management standards on the likelihood of the adoption of ISO 14001 as follows:

Hypothesis 5. The greater the number of existing ISO 9000 certifications within a country, the greater the propensity for ISO 14001 certification within that country in early and later phases of diffusion of the standard.

\section{Geographical Proximity}

The cognitive aspects of the institutional environment refer to the cultural elements that govern choice, often without receiving conscious thought (DiMaggio \& Powell, 1983; Hoffman and Ventresca, 1999; Zucker, 1983). Scholars have shown that, among other factors, the importance of geographical proximity between individuals in the transmission of tacit knowledge can explain the geographic concentration of economic activity (Desrochers, 1998). Numerous studies have identified geographical proximity as a primary determinant of innovation adoption (Berry and Berry, 1994; Daley and Garand, 2005). March and Simon (1958) recognized that decision makers operate under cognitive constraints and tend to conduct limited searches 
among available alternatives to obtain satisfactory solutions. Firms will be likely to limit their searches about environmental management systems to contexts that are close geographically and therefore often culturally. Indeed, some firms might adopt ISO 14001 because they learn about it from adopters operating in their geographical proximity. Some earlier studies confirm this effect (Albuquerque et al., 2007; Prakash \& Potoski, 2007). Once an innovation has diffused broadly, as Tolbert and Zucker (1996) argued, firms might adopt it for legitimation reasons. We therefore argue that geographical proximity might play a bigger role in the later phases of diffusion because it requires a broader set of adopters to be an effective vehicle of diffusion. We therefore hypothesize the following:

Hypothesis 6 . The greater a country's geographical proximity to countries with ISO 14001 certifications, the greater the propensity for ISO 14001 certification within that country in later phases of diffusion of the standard.

In summary, we argue that coercive, normative, and cognitive elements of the institutional environment may shape the adoption of a standard. Each of these factors, however, may play a more or less important role, depending on the stage of the diffusion of the standard. We make the case that although past research (Delmas, 2003; Neumayer \& Perkins, 2004; Potoski \& Prakash, 2004; Prakash \& Potoski, 2006; Xia et al., 2008), which has focused largely on the early stages of diffusion, has identified factors related to the role of government and environmental NGOs as particularly significant, these forces might play a lesser role in the later phases of diffusion. Furthermore, in the take-up phase of the standard, coercive forces and normative forces might oppose each other, whereas this opposition might fade over time.

\section{Data and Method}

We have compiled a panel dataset of the total number of ISO 14001-certified facilities in 139 countries between 1996 and 2006 (see Appendix). In our sample, 115 countries had at least one certificate in the year 2006 and the remaining twenty-four countries had none.

The dependent variable is the number of facilities certified in each country between 1996 and 2006, as recorded by the ISO in Geneva. The reference month for the number of certificates was December of each year. We obtained measures for the independent variables from other secondary data sources. We measured all independent variables with a one-year lag. We undertook three analyses. The first analysis includes the take-off period, from 1996 to 2000 , before 50 percent of the countries had adopted ISO 14001 . The second analysis comprises the later phase of diffusion, from 2001 to 2006 . The third analysis includes the eleven-year period from 1996 to 2006 .

The method used to choose the cut-off year for the take-up phase versus the later phase follows the methodology used in the literature of diffusion (for a review, see Mahajan, Muller, and Wind, 2000). Studies in the diffusion literature classify adopters into groups according to the timing of each firm's adoption relative to the percentage of the total population that adopted the new practice. Based on the 
normal adopter distribution, mean time of adoption, and its standard deviation, Rogers (1962) classifies the "early majority" as the first 50 percent of adopters. In our case, we use the 50 percent adoption threshold to differentiate between early joiners and late joiners. Our population consists of all sovereign country members of the UN, that is, 192 countries. By 2000, ninety-six of these 192 countries had at least one ISO 14001 certification (50 percent threshold) and were classified as early joiners (see Figure 1). In addition, 2000 was the year the ISO revised the ISO 14001 standard. These elements indicate that after 2000 , the standard entered a more mature phase of existence.

\section{Governmental Commitment to Environmental Protection and}

\section{Management Standards}

We use three measures to assess governmental commitment toward the environment. The first one concerns "governmental effectiveness," the second one "voice and accountability," and the third one "the number of international environmental treaties ratified by each country."

"Governmental effectiveness" and "voice and accountability" are aggregated measures taken from the governance indicators the World Bank (2007) compiled from a variety of sources. "Governmental effectiveness" measures the perception of the quality of public service provision, the quality of the bureaucracy, the competence of civil servants, the independence of the civil service from political pressure, and the credibility of governments' commitment. The main focus of this index is on "inputs" required for the government to be able to produce and implement good policies. "Voice and accountability" includes a number of indicators measuring various aspects of the political process, civil liberties, and political rights. These indicators measure the extent to which citizens of a country are able to participate in the selection of governments. Also included in this category are three indicators measuring the independence of the media, which serves an important role in monitoring those in authority and holding them accountable for their actions.

Several authors have used the international environmental treaties as a proxy to measure governmental commitment to environmental protection (Corbett \& Kirsch, 2001; Delmas \& Montiel, 2008; Frank, 1997). The EarthTrends Data Tables on Environmental Institutions and Governance from the World Resources Institute and United Nations Environment Programme GEO Data Portal identify thirteen main international environmental treaties and provide information on ratification dates (EarthTrends, 2005). ${ }^{2}$ The commitment variable was calculated by dividing the number of the environmental treaties each country ratified by the total available environmental treaties in each year. Countries with a higher score can thus be considered as having a higher commitment on the international environmental scene.

In view of the fact that variables representing governmental effectiveness, voice and accountability, and commitment of a country toward environmental issues are highly correlated (all the correlations being higher than 0.7 ), we created a single factor for governmental commitment for the environment based on the principal component analysis of these three variables. Since the first principal component explained 85 percent of the total variation among environmental government com- 
mitment variables and had the largest correlation with the dependent variable, it was saved and from then on treated as an independent variable called environmental government commitment. The first principal component gave positive weights to all of the variables; therefore, we can think of the factor for environmental government commitment as the "average" effect of governmental effectiveness, voice and accountability, and commitment of a country toward environmental issues.

The ISO provides the list of countries that participated in the design process of the ISO 14001 certification. We coded the participation of a country in the ISO TC 207 committee, in charge of the design of ISO 14001, as a binary variable (value of 1 assigned to participating countries).

We also include a variable to represent the number of European Commission EMAS certifications in the focal country divided by the total number of EMAS certifications.

\section{Environmental Law Firms}

As a proxy for the level of litigation, we have created a variable measuring the number of environmental law firms, per capita, in each country (Delmas, 2003; Potoski \& Prakash, 2004). The data for this variable were taken from the Martindale-Hubbell International Law Directory (1995-2005). Note that this measure may exhibit some bias toward U.S.-based companies because a U.S. company published the directory, but the regression results we report below are not sensitive to the exclusion of the United States (more detailed results are available from the authors upon request).

\section{Diffusion of Management Standards}

To represent existing experience with other international management standards, we include a variable representing the number of ISO 9000 certifications in the focal country divided by the total number of ISO 9000 certifications in the world, data we obtained from the ISO in Geneva.

The Role of Civil Society

To measure the degree of pressure civil society exerts, we introduced a variable representing the number of international NGOs in each country. We gathered these data from the Yearbook of International Organizations. We use the number of international NGOs in each country as a proxy for the degree of civil society involvement in international policy issues (Delmas \& Montiel, 2008).

Cohesion in Trade and Role of Trade Equivalence

To approximate cohesion in trade, we adapted the measure Guler, Guillen, and MacPherson (2002) developed, which captures how strongly a country is tied to other countries through trade and the extent to which ISO certificates have already diffused in these countries. Unlike Guler, Guillen, and MacPherson, however, we used ISO 14001 certificates instead of ISO 9000 . Formally, the cohesion in trade measure for country $i$ at time $t$ is

$$
\text { Cohesion in } \operatorname{Trade}_{i t}=\Sigma_{\mathrm{j}} \text { ISO } 14001_{\mathrm{jt}-1} \times\left(\operatorname{Trade}_{\mathrm{ij}} / \operatorname{Trade}_{\mathrm{i}}\right)^{2}
$$


where $\mathrm{ISO}_{\mathrm{jt}-1}$ is the number of certificates for country $\mathrm{j}$ at time $\mathrm{t}-1$, Trade $\mathrm{ij}_{\mathrm{ij}}$ is the trade from country $i$ to country $j$ averaged over 1995-2000, and Trade ${ }_{\mathrm{i}}$ is country $i$ 's total trade during the same period. The data on trade ties between each pair of countries come from Feenstra 2000.

To capture the effect of role equivalence in trade, we also adapted the measure Guler, Guillen, and MacPherson (2002) developed, and calculated how much a country's pattern of exports and imports by product category overlaps with those of the other countries, weighted by the extent to which ISO 14001 certification has already diffused in each of the other countries:

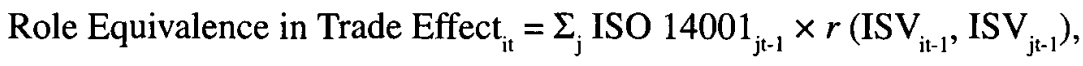
where ISO $14001_{t-1}$ is the number of certificates held by country $\mathrm{j}$ in year $\mathrm{t}-1$ and $r$ is the Pearson correlation coefficient between the industry share vectors for countries $i$ and $j$ during year $\mathrm{t}-1$. The ISV vector is the combination of import and export industry share vectors for each country $i$ in the period $t-1$ (for more details, see Guler et al., 2002). We obtained the trade matrices we used to calculate cohesion and role equivalence from Feenstra (2000).

\section{Countries' Geographical Proximity}

We include a measure of the geographical proximity of countries computed as the total number of ISO 14001 certificates for bordering countries measured at a oneyear lag.

\section{Control Variables}

We control for the size of a country's economy by using Gross Domestic Product (GDP) converted to constant international dollars using Purchasing Power Parity (PPP) rates, as reported by the World Bank's World Development Indicators Database. Several previous studies have also used GDP has been used as a deflator (Corbett \& Kirsch, 2001; Delmas \& Montiel, 2008; Guler et al., 2002; Potoski \& Prakash, 2004). We also control for the impact of the presence of foreign multinationals using the variable foreign direct investment stocks (FDI) from the United Nations Conference on Trade and Development website. Table 1 presents the descriptive statistics and the correlation coefficients of the variables used in this study.

\section{Estimation}

The dependent variable, which represents the number of ISO 14001 certificates per country, has two important characteristics: it is a count variable, and it includes both many observations clustered at zero and several observations in the far-right tail of the distribution, resulting in a variance higher than the mean and therefore over-dispersion. Poisson regression is specifically designed for count-dependent variables. It assumes, however, that the mean and variance of the events counts are equal (Greene, 2003). When individual counts are more dispersed than the Poisson model, the negative binomial model can be used because the regression model includes a random term reflecting unexplained between-subject differences (Gardner, Mulvery, and Shaw, 1995). We therefore estimated a panel negative binomial model with robust standard errors for three periods: the entire period (1996-2006), the 
Table 1: Descriptive statistics ( $N=1511$ observations, 139 countries)

\begin{tabular}{|c|c|c|c|c|c|c|c|c|c|c|c|c|c|c|c|}
\hline \multicolumn{16}{|c|}{ Correlations } \\
\hline & Variable & Mean & $\begin{array}{l}\text { Std. } \\
\text { Dev. }\end{array}$ & 1 & 2 & 3 & 4 & 5 & 6 & 7 & 8 & 9 & 10 & 11 & 12 \\
\hline 1 & ISO 14001 Certification & 343.10 & 1512.54 & 1.00 & & & & & & & & & & & \\
\hline 2 & Env government commitment & -0.02 & 1.02 & $0.25^{*}$ & 1.00 & & & & & & & & & & \\
\hline 3 & Participation in the design & 0.53 & 0.49 & $0.19^{*}$ & $0.49^{*}$ & 1.00 & & & & & & & & & \\
\hline 4 & Environmental lawyers & 1.04 & 3.88 & $0.10^{*}$ & $0.28^{*}$ & $0.14^{*}$ & 1.00 & & & & & & & & \\
\hline 5 & ISO 9000 certification & 0.71 & 2.46 & $0.51^{*}$ & $0.35^{*}$ & $0.25 *$ & $0.19 *$ & 1.00 & & & & & & & \\
\hline 6 & EMAS & 0.72 & 6.10 & $0.16^{*}$ & $0.20^{*}$ & $0.10^{*}$ & 0.00 & $0.28 *$ & 1.00 & & & & & & \\
\hline 7 & Cohesion in trade & 4.76 & 1.74 & $0.12^{*}$ & $0.07 *$ & -0.03 & 0.04 & -0.03 & $-0.06^{*}$ & 1.00 & & & & & \\
\hline 8 & Role equivalence in trade & 6.03 & 2.63 & $0.52 *$ & $0.54 *$ & $0.43^{*}$ & $0.18^{*}$ & $0.48^{*}$ & $0.22 *$ & $0.30^{*}$ & 1.00 & & & & \\
\hline 9 & Geographical proximity & 3.43 & 3.01 & $0.27 *$ & $0.38^{*}$ & $0.32^{*}$ & $0.07 *$ & $0.21^{*}$ & $0.16^{*}$ & $0.37^{*}$ & $0.54^{*}$ & 1.00 & & & \\
\hline 10 & Civil society organizations & 6.86 & 1.70 & $0.22 *$ & $0.39^{*}$ & $0.52 *$ & $-0.06^{*}$ & $0.28^{*}$ & $0.14^{*}$ & $0.17^{*}$ & $0.57 *$ & $0.38^{*}$ & 1.00 & & \\
\hline 11 & GDP ppp & 10.77 & 2.06 & $0.37 *$ & $0.43^{*}$ & $0.60^{*}$ & $0.14^{*}$ & $0.45^{*}$ & $0.19 *$ & $0.05^{*}$ & $0.60^{*}$ & $0.46^{*}$ & $0.58^{*}$ & 1.00 & \\
\hline 12 & FDI & 5.85 & 2.09 & $0.19 *$ & $0.70^{*}$ & $0.47^{*}$ & $0.29 *$ & $0.26^{*}$ & $0.14^{*}$ & $0.24^{*}$ & $0.59 *$ & $0.43^{*}$ & $0.27^{*}$ & $0.38^{*}$ & 1.00 \\
\hline
\end{tabular}


take-off phase of ISO 14001 certification (1996-2000), and the later phase of ISO 14001 certification (2001-2006).

\section{Results}

Through the consideration of three possible models, Table 2 presents the test of the effects of the independent variables on the adoption of ISO 14001. Model 1 represents the period between 1996 and 2000. Model 2 represents the period between 2001 and 2006. Model 3 represents the entire period from 1996 to 2006. Within each of these models, we first present the results with the control variables only, then the results with the control variables and regulative variables, and finally the full model.

Hypothesis 1 states that governmental commitment to the environment will contribute positively to the number of ISO 14001 certifications in the early phase of adoption of the standard. In Model 1, the effects of the variable representing governmental commitment to the environment are positive and significant $(\mathrm{p}<0.01)$. The effect is insignificant in the second period (Model 2) and in the full period (Model 3 ). The variable representing EMAS is positive and significant $(\mathrm{p}<0.10)$ but only in the early period. The variable representing government involvement in the design of ISO 14001 is positive and significant in Models 1 and $2(p<0.01)$, but the coefficient is reduced in Model 2. Thus Hypothesis 1 is confirmed for government environmental commitment and EMAS and partially confirmed for the involvement of a government in the design of ISO 14001.

Hypothesis 2 predicts that civil society organizations will positively impact the adoption of ISO 14001 in the take-off period of the standard. The variable representing civil society organizations is positive and significant in the first period (Model 1) $(\mathrm{p}<0.05)$. The significance is reduced in the second period (Model 2) $(\mathrm{p}<0.10)$.

Hypothesis 3 a predicts the number of certificates in the focal country will be positively related to the number of certificates in those countries to which the focal country is directly tied in the trade network. The results support this hypothesis as well, with coefficients that are positive and significant in all models $(\mathrm{p}<0.01)$. Hypothesis $3 \mathrm{~b}$ predicts the number of certificates in the focal country will be positively related to the number of certificates in those countries with which the focal country is competing. The coefficient of the variable representing the role equivalence in trade is also significant. Interestingly, we find that the coefficient for cohesion in trade, representing coercive pressure, is reduced in the second period. By contrast, the coefficient for equivalence in trade is increased in the second model, shown in increased effect of normative forces related to trade. This confirms Hypothesis 3.

Hypothesis 4 predicts firms will be less likely to adopt ISO 14001 in a national context where the number of environmental lawyers is very high-because high numbers of lawyers could discourage firms from exposing themselves to the potential for litigation. In the first model, representing the take-off period of ISO 14001, the coefficient of the variable representing the number of environmental lawyers has a negative value and is significant $(\mathrm{p}<0.05)$. The significance disappears in the models representing the 2001-6 time period and the full period. This confirms Hypothesis 4. 
Table 2. Negative binomial with robust standard errors and lagged dependent variable

\begin{tabular}{|c|c|c|c|c|c|c|c|c|c|}
\hline & \multicolumn{3}{|c|}{$\begin{array}{l}\text { (1) ISO } 14001 \\
\text { Certification }(1996-2000)\end{array}$} & \multicolumn{3}{|c|}{$\begin{array}{c}\text { (2) ISO } 14001 \\
\text { Certification (2001-2006) }\end{array}$} & \multicolumn{3}{|c|}{$\begin{array}{l}\text { (3) ISO 14001 } \\
\text { Certification (1996-2006) }\end{array}$} \\
\hline & $\mathbf{A}$ & $\mathbf{B}$ & C & $\mathbf{A}$ & B & $\mathbf{C}$ & $\mathbf{A}$ & B & C \\
\hline $\begin{array}{l}\text { Env } \\
\text { government }\end{array}$ & & $0.32^{*}$ & $0.24^{*}$ & & 0.16 & 0.08 & & 0.12 & -0.03 \\
\hline commitment & & $(0.17)$ & $(0.12)$ & & $(0.11)$ & $(0.06)$ & & $(0.08)$ & $(0.06)$ \\
\hline $\begin{array}{l}\text { Participation } \\
\text { in ISO }\end{array}$ & & $1.33 * *$ & $0.64^{* *}$ & & $0.90^{* *}$ & $0.68 * *$ & & $1.70^{* *}$ & $0.88 * *$ \\
\hline design & & $(0.35)$ & $(0.25)$ & & $(0.21)$ & $(0.14)$ & & $(0.30)$ & $(0.15)$ \\
\hline \multirow[t]{2}{*}{ EMAS } & & $0.02 * *$ & $0.01 *$ & & 0.01 & 0.00 & & 0.01 & 0.00 \\
\hline & & $(0.01)$ & $(0.00)$ & & $(0.01)$ & $(0.00)$ & & $(0.01)$ & $(0.00)$ \\
\hline Civil society & & $0.47 * *$ & $0.25^{*}$ & & $0.18+$ & $0.09+$ & & $0.33 * *$ & $0.16^{* *}$ \\
\hline organizations & & $(0.18)$ & $(0.13)$ & & $(0.11)$ & $(0.05)$ & & $(0.08)$ & $(0.05)$ \\
\hline \multirow[t]{2}{*}{$\begin{array}{l}\text { Cohesion in } \\
\text { trade }\end{array}$} & & $0.49 * *$ & $0.30^{* *}$ & & $0.30^{* *}$ & $0.17 * *$ & & $0.41 * *$ & $0.29 * *$ \\
\hline & & $(0.10)$ & $(0.08)$ & & $(0.06)$ & $(0.05)$ & & $(0.05)$ & $(0.05)$ \\
\hline $\begin{array}{l}\text { Role } \\
\text { equivalence in }\end{array}$ & & & $0.38 * *$ & & & $0.62 * *$ & & & $0.56^{* *}$ \\
\hline trade & & & $(0.04)$ & & & $(0.03)$ & & & $(0.02)$ \\
\hline Environmental & & & $-0.04^{*}$ & & & 0.01 & & & 0.01 \\
\hline lawyers & & & $(0.02)$ & & & $(0.01)$ & & & $(0.01)$ \\
\hline ISO 9000 & & & $0.01+$ & & & $0.02 * *$ & & & $0.02 * *$ \\
\hline certification & & & $(0.01)$ & & & $(0.01)$ & & & $(0.00)$ \\
\hline Geographical & & & 0.01 & & & $0.07 * *$ & & & $0.07 * *$ \\
\hline proximity & & & $(0.03)$ & & & $(0.02)$ & & & $(0.02)$ \\
\hline \multirow[t]{2}{*}{ GDP ppp } & $0.84 * *$ & $0.57 * *$ & $0.53 * *$ & $0.46^{* *}$ & $0.28 * *$ & $0.06+$ & 0.10 & 0.06 & 0.04 \\
\hline & $(0.07)$ & $(0.09)$ & $(0.06)$ & $(0.04)$ & $(0.06)$ & $(0.03)$ & $(0.06)$ & $(0.04)$ & $(0.04)$ \\
\hline \multirow[t]{2}{*}{ FDI } & $0.43^{* *}$ & $0.33^{* *}$ & $0.28 * *$ & $0.30^{* *}$ & $0.16^{* *}$ & 0.02 & $0.27 * *$ & $0.17 * *$ & $0.07^{*}$ \\
\hline & $(0.06)$ & $(0.08)$ & $(0.06)$ & $(0.04)$ & $(0.06)$ & $(0.03)$ & $(0.03)$ & $(0.04)$ & $(0.03)$ \\
\hline ISO 14001 & 0.00 & 0.00 & 0.00 & $0.00^{*}$ & $0.00^{*}$ & $0.00^{*}$ & $0.00^{*}$ & $0.00^{*}$ & $0.00^{*}$ \\
\hline $\begin{array}{l}\text { certification } \\
(\mathrm{t}-1)\end{array}$ & $(0.00)$ & $(0.00)$ & $(0.00)$ & $(0.00)$ & $(0.00)$ & $(0.00)$ & $(0.00)$ & $(0.00)$ & $(0.00)$ \\
\hline \multirow[t]{2}{*}{ Constant } & $-13.40 * *$ & $-14.95 * *$ & $-13.40 * *$ & $-6.24 * *$ & $-6.88 * *$ & $-6.56 * *$ & $-10.43^{* *}$ & $-9.05^{* *}$ & $-7.02 * *$ \\
\hline & $(1.05)$ & $(1.24)$ & $(0.89)$ & $(0.55)$ & $(0.83)$ & $(0.51)$ & $(0.29)$ & $(0.60)$ & $(0.53)$ \\
\hline Observations & 689 & 689 & 689 & 822 & 822 & 822 & 1511 & 1511 & 1511 \\
\hline $\begin{array}{l}\text { No. of } \\
\text { countries }\end{array}$ & 139 & 139 & 139 & 139 & 139 & 139 & 139 & 139 & 139 \\
\hline $\begin{array}{l}\text { Countries with } \\
\text { ISO } 14001\end{array}$ & 76 & 76 & 76 & 115 & 115 & 115 & 115 & 115 & 115 \\
\hline
\end{tabular}

Hypothesis 5 predicts that the greater the diffusion of process standards, the more likely it is that ISO 14001 will be adopted. The variable representing the number of ISO 9000 certifications is positive and significant in all models, however, it is only marginally significant in Model $1(\mathrm{p}<0.10)$ as compared to Models 2 and 3 ( $\mathrm{p}<$ 0.001). This confirms Hypothesis 5.

Hypothesis 6 predicts geographical proximity will play a role in later phases of diffusion. We find a significant and positive effect of the variable representing geographical proximity in models 2 and 3 but an insignificant effect in Model 1 . 
Therefore, geographical proximity seems to play a more important role in the later phases of diffusion than in the early phases of diffusion.

Turning to the control variables, similar to other studies, countries with higher GDP are more likely to adopt ISO 14001 . The role of FDI is significant in Model $1(\mathrm{p}<0.001)$ and $3(\mathrm{p}<0.005)$ but not in Model 2.

In summary, our results show that some of the coercive elements of national environments may play a more important role in the earlier stages of diffusion of ISO 14001 than in later phases. The results sustain the assertion that the greater the governmental commitment to the environment and to environmental management systems, and the greater the pressures from civil society, the more likely firms are to adopt ISO 14001 in the early phase of the diffusion of the standard. In the later phases of diffusion, we observe an increasing role of normative and cognitive pressures. We find that the greater the experience with process standards such as ISO 9000 within a country, and the greater the geographical proximity with countries that have adopted ISO 14001, the greater the adoption of ISO 14001. We also find that the role of cohesion in trade as well as the role of equivalence in trade are both important in early and later phases of diffusion of the standard although their relative importance varies. Finally, we find that as the standard diffuses, some initial negative reactions, such as those of environmental law firms, lose their significance in the second time period (2001-6).

\section{Discussion and Conclusion}

A lot of speculation has arisen concerning the drivers of firms' adoption of international management standards in the area of the environmental and corporate social responsibility, but limited empirical evidence points to how these standards diffuse over long periods of time and in different national contexts. In this paper, we show the relationship between institutional factors and firms' decisions to adopt an international environmental management standard. The analysis emphasizes that in the case of an emerging standard, the potential lack of consensus within the regulatory/institutional environment concerning the value of a new standard could send mixed signals to firms about the standard. For example, although the government may send positive signals favoring the adoption of environmental management practices, compliance professionals may send negative signals. In an international context, the dynamics that will lead to a degree of social consensus will vary from one country to another. The data suggest that ISO 14001 is more likely to be adopted in a country with (1) a high level of governmental commitment to environmental protection and (2) a low to moderate number of law firms per capita, suggesting relatively low levels of litigation. Although these early-stage findings suggest tension between the "regulative" and "normative" aspects of the legal environment, this tension may well become resolved over time as the actual transaction costs and benefits of the standard become better known. We find that the role of regulative factors on the adoption of ISO 14001 fades in the later phase of diffusion, in which ISO 14001 is mostly adopted because of geographical proximity to countries that have adopted ISO 14001 and in countries with higher rates of adoption of ISO 9000 , 
the international quality management standard. The role of government participation in the design of the standard appears to be important both in early and later phases of diffusion of the standard. This result shows that although the coercive role of government might not persist over time, more normative pressures from the government might have a more persistent effect. Countries involved in the design of ISO 14001 may have had a better understanding of the appropriate incentives to promote the standard over a long period of time. Such countries may also have been able to influence the design of ISO 14001 so it would match their characteristics and facilitate adoption. Previous studies identified some of the coercive elements of the environment as important drivers of the adoption of ISO 14001 (Delmas, 2003; Neumayer \& Perkins, 2004; Prakash \& Potoski, 2006; Potoski \& Prakash, 2004; Xia et al., 2008). However, rare are the studies that compare different phases of the international diffusion of ISO 14001 (Albuquerque et al., 2007). Our study contributes to the literature of ISO 14001 diffusion by highlighting how the intensity of such forces may vary over more than a decade.

More broadly, this study contributes to the institutional theory perspective by examining the effect of higher-level institutional influences at the broad societal level on the adoption of various practices within countries. Although Tolbert and Zucker (1983) emphasized that early adopters and late adopters of management practices and technologies face different pressures from their institutional environment and therefore may implement the same practice differently (see also Westphal et al., 1997), their analysis focused on a single national context. Building on this work, we are able to show, at the international level, the importance of coercive forces, which might provide more direct rewards in the initial adoption period, and of normative forces in the later phases of the international diffusion of ISO 14001. Tolbert and Zucker argue that early joiners are mostly interested in the technical efficiency of a practice, whereas followers are subjected to more institutional pressures. In this stream of research, early joiners are considered to function out of their institutional contexts. As Westphal and colleagues noted, earlier adopters are "motivated by the opportunity for efficiency gains and free from the 'iron cage' of isomorphic pressures" (1997: 374). In our study, we challenge these assumptions. We demonstrate the importance of the national institutional pressures and we highlight the possibility that "negative" normative forces can influence behavior in the early phases of diffusion. This view is consistent with Delmas and Montes-Sancho (2010), who found that early joiners of environmental voluntary programs respond to political pressures at the state level, as well as to peer pressure exerted by their trade association.

Our analysis also enriches the institutional model by showing that similar organizations can exert regulative normative or cognitive pressures either simultaneously or sequentially. Most prior studies have treated the effects of the regulative and normative aspects of the institutional environment as being independent of one another, with normative aspects of the legal environment, in particular, rarely being considered. We find support instead for the expectation that the legal environment is constituted through the interaction between government policies and professional influence, and that the legal environment will incorporate both regulative and normative forces, which can work against each other in the case of the adoption of a 
management standard. In particular, this study extends the findings of Edelman, Uggen, and Erlanger (1999) and Sutton and Dobbin (1996), who highlighted the role of compliance professionals, in two directions. First, whereas they showed that compliance professionals encourage the legalization of employment practices, we describe how compliance professionals can exaggerate the threat of misuse of information and actually discourage managers from adopting ISO 14001. In this study, compliance professionals could be an impediment to the adoption of a standard. They contest the value of a standard that in principle aims at helping companies comply with existing regulations. We do not argue these compliance professionals would personally lose from the diffusion of ISO 14001, but rather that they were playing their expected role, which is to highlight the risks of a standard in a specific legal context. Second, we compare internationally the importance of norms within the legal environment.

Likewise, when analyzing the role of multinationals, we describe how multinationals could exert coercive or normative pressure and how these evolve over time. Previous studies have identified the importance of trade relations in explaining the adoption of ISO 14001 (Albuquerque et al., 2007; Delmas \& Montiel, 2008; Neumayer \& Perkins, 2004; Prakash \& Potoski, 2006; Xia et al., 2008). Our analysis builds on these studies to describe the coercive and normative mechanisms through which multinationals could facilitate the adoption of ISO 14001. In summary, we provide a more complex model of institutional pressures, where coercive and normative pressures can be exerted by the same organizations either sequentially or at the same time.

Finally, our model can inform the business ethics literature in several ways. First, our model provides evidence of the strength and enduring power of normative forces. Wry (2009) suggests that the business ethics literature would benefit from breaking from strategic or moral argument to embrace theoretical approaches, which provide a cultural lens on corporate behavior. Institutional theory emphasizes legitimation processes and the tendency for institutionalized organizational structures and procedures to be taken for granted, regardless of their efficiency implications (Hoffman and Ventresca, 2002). As Scott (1995) argues, technical forces primarily shape "core functions" including work units and coordinating arrangements, whereas institutional forces shape more "peripheral" structures such as managerial and governance systems. Institutional theory can therefore help explain the factors that favor the adoption of ethical practices by organizations within national contexts beyond economic or moral rationales. We highlight the importance of national institutional pressures for determining the success a specific strategy: the adoption of ISO 14001 . Our framework can be useful to the business ethics literature in helping to influence the creation and maintenance of favorable institutions.

For example, the ISO issued ISO 26000, which aims to assist organizations to improve their social responsibility performance (Castka and Balzarova, 2008). Because of the similarity between the standardization for social responsibility and for environmental responsibility, our research may inform the diffusion of corporate social accountability standards. 
First, stakeholders have to legitimize the implementation of corporate social accountability standards (Gilbert \& Rasche, 2007). However, stakeholders across countries, and also within a national institutional environment, may have different views about corporate social responsibility. As Castka and Balzarova (2008) mentioned, a disparity of views among different stakeholders concerning the approach to take arose in the development of ISO 26000. Disparity of opinion in the development of the standard is likely to be representative of a diversity of opinion within national institutional contexts. Second, corporate social responsibility is difficult to measure and there is a lot of uncertainty about its actual meaning (Waddock and Graves, 1997). Third, standards such as ISO 26000 bear important similarities to ISO 14001: they are based on processes not outcomes. Also note that ISO 26000 in its current form is a guidance document and does not include third-party certification.

We can expect countries with governments involved in the development of the ISO 26000 standard to most likely be the first in which firms adopt ISO 26000 . We can also expect countries with higher number of environmental NGOs to be first adopters. Because of the similarity between ISO 14001 and ISO 26000, we can expect countries with high levels of ISO 14001 adoption to also be countries with higher levels of ISO 26000 adoption. Finally, legal systems might have an impact on the adoption of ISO 26000 because of the broad differences in how social issues are regulated across the world.

Future research may well be able to examine the ways in which the dynamics of initial adoption and later diffusion may interact with the characteristics of a given innovation, just as previous research on product standards has shown that the specifics of the products have an important bearing on their diffusion curves (see, e.g., the summary by Rogers, 1962). Just as Teece (1980), for example, has argued that some similarities exist in the diffusion processes of product and administrative innovations, future studies should investigate the role of the specific characteristics of a management standard on its likely diffusion. In this paper, we postulate that institutional factors may be especially important in explaining the diffusion of ISO 14001 because of the incompleteness of the standard in dealing with the measurement of environmental performance. But why was such an "incomplete" standard enacted in the first place? Further research could investigate whether the institutional forces at play for the creation of a standard could be related to those that hamper or facilitate its diffusion. Further research could also test empirically whether institutional forces play a similar role for the adoption of other international corporate social accountability standards that might place more emphasis on transparency and performance measurement.

\section{NOTES}

Acknowledgments: We appreciate many insightful comments from William Freudenburg. The authors acknowledge financial support from the UCLA Center for International Business Education and Research program and the Spanish Ministry of Education and Science grant \# SEJ2007-63996.

1. The most recent of these studies analyzed ISO data until 2002 (Prakash \& Potoski, 2006, 2007; Albuquerque, Bronnenberg, and Corbett, 2007). Delmas and Montiel (2008) analyzed the ISO data until 2003 in the chemical industry. 
2. The thirteen treaties are the Convention on International Trade in Endangered Species of Wild Fauna and Flora, the United Nations Framework Convention on Climate Change, the Kyoto Protocol, the United Nations Convention on Biological Diversity, the Biosafety Protocol, the United Nations Convention to Combat Desertification, the Stockholm Convention on Persistent Organic Pollutants, the Rotterdam Convention on the trade of hazardous chemical and pesticides, the Basel Convention on the Control of Transboundary Movements of Hazardous Wastes and their Disposal, the Ramsar Convention on the Wetlands, the United Nations Convention on the Law of the Sea, the Convention on the Conservation of Migratory Species of Wild Animals, and the Vienna Convention on the Protection of the Ozone Layer.

\section{REFERENCES}

Abrahamson, E., \& Fairchild, G. 1999. Management fashion: Lifecycles, triggers, and collective learning processes. Administrative Science Quarterly, 44(4): 708-40.

Albuquerque, P., Bronnenberg, B. J., \& Corbett, C. J. 2007. A spatio-temporal analysis of the global diffusion of ISO 9000 and ISO 14001 certification. Management Science, 53(3): 451-68.

Andrews, R. N. L., Amaral, D., Darnall, N., Gallagher, D. R., Edwards Jr., D., Hutson, A., D'Amore, C., Sun, L., \& Zhang, Y. 2003. Environmental management systems: Do they improve performance? Final report of the National Database on Environmental Management Systems Pilot Project. Chapel Hill, N.C.: University of North Carolina-Chapel Hill. Department of Public Policy.

Arias, M. E., \& Guillen, M. F. 1998. The transfer of organizational management techniques. In J. L. Alvarez (Ed.), The diffusion and consumption of business knowledge. London: Macmillan.

Bansal, P., \& Bogner, W. C. 2002. Deciding on ISO 14001: Economics, institutions, and context. Long Range Planning, 35(3): 269-90.

Berry, F. S., \& Berry, W. D. 1994. The politics of tax increases in the states. American Journal of Political Science 38(3): 855-59.

Casper, S., \& Hancke, B. 1999. Global quality norms within national production regimes: ISO 9000 standards in the French and German car industries. Organizational Studies, 20(6): 961-85.

Castka, P., \& Balzarova, M.A. 2008. ISO 26000 and supply chains: On the diffusion of the social responsibility standard. International Journal of Production Economics, 111(2): 274-86.

Coglianese, C., \& Nash, J. 2001. Regulating from the inside: Can environmental management systems achieve policy goals? Washington D.C.: Resources for the Future.

Corbett, C. J., \& Kirsch, D. A. 2001. International diffusion of ISO 14001 certification. Production and Operations Management, 10(3): 327-42.

Christmann, P., \& Taylor, G. 2001. Globalization and the environment: Determinants of firm self-regulation in China. Journal of International Business Studies, 32(3): 439-58.

Daley, D. M., \& Garand, J. C. 2005. Horizontal diffusion, vertical diffusion, and internal pressure in state environmental policymaking 1989-1998. American Politics Research, 33(5): 615-44. 
Darnall, N. 2003. Why firms certify to ISO 14001: An institutional and resource-based view. In D. Nagao (Ed.), Best paper proceedings: Sixty-first meeting of the Academy of Management. Washington, D.C.: Academy of Management.

Delmas, M. 2000. Barriers and incentives to the adoption of ISO 14001 in the United States. Duke Environmental Law and Policy Forum, Fall: 1-38.

2001. Stakeholders and competitive advantage: The case of ISO 14001. Production and Operations Management, 10(3): 343-58.

2002. The diffusion of environmental management standards in Europe and in the United States: An institutional perspective. Policy Sciences, 35(1): 91-119.

2003. In search of ISO: An institutional perspective on the adoption of international management standards. University of California, Santa Barbara, February 2003. http://papers.ssrn.com/sol3/papers.cfm?abstract_id=379800.

Delmas, M., \& Montiel, I. 2008. The diffusion of voluntary international management standards: Responsible Care, ISO 9000, and ISO 14001 in the chemical industry. Policy Studies Journal, 36(1): 65-93.

2009. Greening the supply chain: When is customer pressure effective? Journal of Economics and Management Strategy, 18(1). 171-201.

Delmas, M., \& Terlaak, A. 2002. Regulatory commitment to negotiated agreements: Evidence form the United States, Germany, the Netherlands, and France. Journal of Comparative Policy Analysis, 4(1): 5-29.

Delmas, M.A., \& Montes-Sancho, M. 2010. Voluntary agreements to improve environmental quality: Symbolic and substantive cooperation. Strategic Management Journal, 31(16): 576-601.

Desrochers, P. 1998. A geographical perspective on Austrian economics. The Quarterly Journal of Austrian Economics, 1(2): 63-83.

DiMaggio, P. 1988. Interest and agency in institutional theory. In L. G. Zucker (Ed.), Institutional patterns and organizations: Culture and environment: 3-22. Cambridge, Mass.: Ballinger.

DiMaggio, P., \& Powell, W. 1983. The iron cage revisited: Institutional isomorphism and collective rationality in organizational fields. American Sociology Review, 48(4): $147-60$.

EarthTrends. 2005.Earth Trends datatables on environmentalinstitutionsandgovernance: Globalgovernance,participationinmajormultilateralagreements.http://earthtrends .wri.org/.

Edelman, L. B. 1992. Legal ambiguity and symbolic structures: Organizational mediation of civil rights law. American Journal of Sociology, 97(6): 1531-76.

Edelman, L. B., Uggen, C., \& Erlanger, H. S. 1999. The endogeneity of legal regulation: Grievance procedures as rational myth. American Journal of Sociology, 105(2): 406-54.

Feenstra, R. 2000. World trade flows, 1980-1997. Berkeley: University of California, Davis, Center for International Data.

Frank, D. J. 1997. Science, nature, and the globalization of the environment, 1870-1990. Social Forces, 76(December): 409-35. 
Gardner, W., Mulvey, E. P., \& Shaw, E. C. 1995. Regression analyses of counts and rates: Poisson, overdispersed Poisson, and negative binomial models. Psychological Bulletin, 118: 392-404.

Gilbert, D. U., \& Rasche, A. 2007. Discourse ethics and social accountability: the ethics of SA8000. Business Ethics Quarterly, 17(2): 187-216.

Gray, R. H., Kouhy, R., \& Lavers, S. 1995. Corporate social and environmental reporting: a review of the literature and a longitudinal study of UK disclosure. Accounting, Auditing \& Accountability Journal, 8(2): 47-77.

Gereffi, G., Garcia-Johnson, R., \& Sasser, E. 2001. The NGO-industrial complex. Foreign Policy, July-August: 56-65.

Greene, W. 2003. Econometric analysis (5th ed.). New York: MacMillan.

Guillen, M. F. 1997. Scientific management's lost aesthetic: Architecture, organization, and the Taylorized beauty of the mechanical. Administrative Science Quarterly, 42(4): 682-715.

Guler, I., Guillen, M. F., \& MacPherson, J. M. 2002. Global competition, institutions, and the diffusion of organizational practices: The international spread of the ISO 9000 quality certificates. Administrative Science Quarterly, 47(3): 507-31.

Hoffman, A., \& Ventresca, M. 1999. The institutional framing of policy debates: Economics versus the environment, American Behavioral Scientist, 42(8): 1368-92.

(Eds.). 2002. Organizations, policy and the natural environment: Institutional and strategic perspectives. Stanford, Calif.: Stanford University Press.

Ingram, P., \& Silverman, B. S. (Eds.). 2002. The new institutionalism in strategic management. Burlington, Mass.: Elsevier.

ISO. 2005. The ISO survey of ISO 9000 and ISO 14000 certificates. Geneva: International Standard Organization.

2006. The ISO survey of ISO 9000 and ISO 14000 certificates. Geneva: International Standard Organization.

Kagan, R. A. 2001. Adversarial legalism. The American way of law. Cambridge, Mass.: Harvard University Press.

Kelley, M. R., \& Arora, A. 1996. The role of institution-building in US industrial modernization programs. Research Policy, 25(2): 265-79.

Kollman, K., \& Prakash, A. 2002. EMS-based environmental regimes as club goods: Examining variations in firm-level adoption of ISO 14001 and EMAS in UK, US, and Germany. Policy Sciences, 35(1): 43-67.

La Porta, R. Lopez-de-Silanes, F., \& Shleifer, A. 2008. The economic consequences of legal origins, Journal of Economic Literature, 46: 285-332.

Lazerson, M. 1995. A new phoenix? Modern putting-out in the Modena knitwear industry. Administrative Science Quarterly, 40(1): 34-59.

Levy, B., \& Spiller, P. 1994. The institutional foundations of regulatory commitment: A comparative analysis of telecommunications regulation. Journal of Law Economics and Organization, 10(2): 201-46.

Mahajan, V., Muller, E., \& Wind, Y. (Eds.). 2000. New-Product Diffusion Models. Boston: Kluwer Academic Press. 
Manetti, G., \& Becatti, L. 2009. Assurance services for sustainability reports: Standards and empirical evidence. Journal of Business Ethics, 87(1): 289-98.

March, J. G., \& Simon, H. A. 1958. Organizations. New York: John Wiley \& Sons.

Martindale-Hubbell. 1995-2005. Martindale-Hubbell international law directory. Summit, N.J.

Mazurek, J. 2001. Third-party auditing of environmental management systems: U.S. Registration practices for ISO 14001: National Academy of Public Administration (01-04).

Mendel, P. J. 2001. Global models of organization: international management standards, reforms, and movements. Palo Alto, Calif.: Stanford University Press.

Meyer, J., Boli, J., Thomas, G., \& Ramirez, F. 1997. World society and the nation state. American Journal of Sociology, 103(1): 144-81.

Meyer, J., Frank, D., Hironaka, A., Schofer, E., \& Tuma, N. 1997. The structuring of a world environmental regime, 1870-1990. International Organization, 51(4): 623-51.

Meyer, J., \& Rowan, B. 1977. Institutionalized organizations: Formal structure as myth and ceremony. American Journal of Sociology, 83(2): 333-63.

Moon, S., \& DeLeon, P. 2005. The patterns of institutional interaction and ISO 14001 adoptions. Comparative Technology and Society, 3(1): 35-57.

Mostek, M. 1998. Limited privilege and immunity for self-evaluative environmental audits in Nebraska: moving environmental performance to the next level. Creighton Law Review, 32: 545 .

Neumayer, E., \& Perkins, R. 2004. What explains the uneven take-up of ISO 14001 at the global level? A panel-data analysis. Environment and Planning, 36: 823-39.

Orts, E. W., \& Murray, P. C. 1997. Environmental disclosure and evidentiary privilege. University of Illinois Law Review: 1-69.

Prakash, A., \& Potoski, M. 2006. Racing to the bottom? Trade, environmental governance, and ISO 14001. American Journal of Political Science, 50(2): 347-61.

2007. Investing up: FDI and the cross-country diffusion of ISO 14001 management systems. International Studies Quarterly. 51: 723-44.

Potoski, M., \& Prakash, A. 2004. Regulatory convergence in nongovernmental regimes? Cross-national variation in ISO 14001 adoption. Journal of Politics, 66(3): 885905.

Rasche,A., \& Esser,D.E. 2006. From stakeholder management to stakeholder accountability. Journal of Business Ethics, 65: 251-67.

Reeves, C. A., \& Bednar, D. A. 1994. Defining quality: Alternatives and implications. The Academy of Management Review, 19(3): 419-45.

Ritti, R. R., \& Silver, J. H. 1986. Early processes of institutionalization: The dramaturgy of exchange in interorganizational relations. Administrative Science Quarterly, 31(1): $25-43$.

Rodgers, K. E. 1996. The ISO environmental standards initiative. New York University Environmental Law Journal, 5: 181-275.

Rogers, E. M. 1962. Diffusion of innovations. New York: The Free Press. 
Russo, M. 2001. Institutions, exchange relations, and the emergence of new fields: Regulatory policies and independent power production in America, 1978-1992. Administrative Science Quarterly, 46(1): 57-86.

Russo, M. V. 2002. Institutional change and organizational strategy: ISO 14001 and toxic emissions in the electronics industry. In D. Nagao (Ed.), Academy of Management Best Papers Proceedings.

Scott, W. R. 1995. Institutions and Organizations. Thousand Oaks, Calif.: Sage.

Sitkin, S. B., Sutcliffe, K. M., \& Schroeder, R. G. 1994. Distinguishing control from learning in total quality management: A contingency perspective. The Academy of Management Review, 19(3): 537-64.

Sutton, J. R., \& Dobbin, F. 1996. The two faces of governance: Response to legal uncertainty in US firms, 1955 to 1985. American Sociological Review, 61(5): 794-811.

Teece, D. J. 1980. The diffusion of an administrative innovation. Management Science, 26(5): 464-70.

Tolbert, P. S., \& Zucker, L. G. 1983. Institutional sources of change in the formal structure of organizations: The diffusion of civil service reform, 1880-1935. Administrative Science Quarterly, 28(1): 22-39.

1996. The institutionalization of institutional theory? In S. R. Clegg, C. Hardy, \& W. R. Nord (Eds.), Handbook of organization studies: 175-190. London: Sage.

Uzumeri, M. V. 1997. ISO 9000 and other metastandards: Principles for management practice? Academy of Management Executive, 11(1): 21-36.

Waddock, S. A., \& Graves, S. B. 1997. The corporate social performance financial performance link. Strategic Management Journal, 18(4): 303-19.

Watkins, R. V., \& Gutzwiller, E. C. 1999. Buying into ISO 14001. Occupational Health \& Safety, 68(2): 52-54.

Westney, D. E. 1987. Imitation and innovation: The transfer of Western organizational patterns to Meiji Japan. Cambridge, Mass.: Harvard University Press.

Westphal, J. D., Gulati, R., \& Shortell, S. M. 1997. Customization or conformity? An institutional and network perspective on the content and consequences of TQM adoption. Administrative Science Quarterly, 42(2): 366-94.

Wry, T. E. 2009. Does business and society scholarship matter to society? Pursuing a normative agenda with critical reaslims and neoinstitutional theory. Journal of Business Ethics, 89: 151-71.

Xia, J., Wang, J., Wang, Y., \& Xing, R. 2008. Stakeholder pressures and the global diffusion of the ISO 14001 initiative: A resource dependence perspective. International Journal of Sustainable Society, 1(1): 4-28.

Zucker, L. G. 1983. Organizations as institutions. In Samuel B. Bacharach (Ed.), Perspectives in organizational sociology: Theory and research (ASA Series), vol. 2. Greenwich, Conn.: JAI Press. 
